\title{
The Effects of Age Factor on Learning English: A Case Study of Learning English in Saudi Schools, Saudi Arabia
}

\author{
Elsadig Mohamed Khalifa Gawi \\ The Applied Medical College, Shaqra University, Saudi Arabia \\ Tel: 96-650-138-9035 E-mail: sadig_99@yahoo.com
}

Received: August 10, 2011

Accepted: September 21, 2011

Published: January 1, 2012

doi:10.5539/elt.v5n1p127

URL: http://dx.doi.org/10.5539/elt.v5n1p127

\begin{abstract}
The purpose of this study is to investigate the effect of age on learning English in Saudi Arabia. It aims at encouraging the learning of English as a foreign language at an early age in KSA. The populations of the study are English language teachers and Saudi students in elementary schools compared with intermediate school students in Dawadmi town. The study found out that age affects EFL learning because early exposure to language instructions constantly results in better performance. The results show that start learning English at an earlier age is an important factor in enhancing the skills of English language learners.
\end{abstract}

Keywords: Starting age $-\mathrm{CPH}=$ Critical Period Hypothesis

\section{Introduction}

The widespread belief that the younger the better in second or foreign language learning is partly grounded on observations of many English teachers and experts all over the world. Evidence for this is drawn from majority language children in schools who start learning English at a very early age in Dawadmi, KSA. International empirical research has shown that a person who starts learning a foreign language very early in his life generally acquire higher level of proficiency than those who begin at later stages (Penfield, 1967; Taylor and Taylor, 1990; and Snow, 1993). However, other studies assumed that starting age will have the same influence on students of a foreign language, when they are exposed to only one speaker of that language (the teacher who is not usually a native speaker) in only one setting (the classroom) and only during very limited amount of time.

From those who were interested in L2/FL learning, began the motivation to investigate the process of acquisition of a foreign language by learners with different starting ages.

In this study, the researcher examines EFL learning in Dawadmi schools. Different age groups for starting learning English as a foreign language are considered. They are surrounded by their native Arabic environment. The settings are both public and private schools for males and females under the supervision of the Ministry of Education in Saudi Arabia.

\subsection{Statement of the Problem}

In the past, pupils in KSA started learning English at intermediate schools in the age of 13 up to 18 in secondary schools. They study four periods weekly on an average school's year extends from 30-32 weeks. This situation continues for six years. Theoretically, this should enable them to learn the language successfully. However, their performance is very weak.

\subsection{The Main Question of the Study}

Is there a significant difference between Saudi students who start learning English at age 5/6 as compared with those who do it at age $12 / 13$ ?

\subsection{Hypothesis of the Study}

Students who start learning English at an earlier age (5/6) attain higher level of proficiency than those who start at later age (12/13).

\subsection{Significance of the Study}

This study is targeting English teachers, students, syllabus designers and decision makers.

Its findings can help the Ministry of Education in KSA and other Arab countries in their objectives to improve 
English instructions in public education.

\section{The Study}

\subsection{Tools of Data Collection}

1. Questionnaire for English teachers.

2. Test for students.

\subsection{Population}

The population of this study from which subjects were drawn can be divided into two categories, these are: Saudi EFL students in Dawadmi (178 students) and English teachers who teach those students or their counterparts (62 teachers).

\subsection{Methodology}

1. The researcher uses (SPSS) to analyze the data collected by the questionnaire and students' test.

2. The general research approach was experimental investigated and examined one independent variable which is the age.

The questionnaire is an instrument used to collect data from English teachers in Dawadmi. The main part consists of 31 items arranged in a 5- Likert Scale Format ranging from strongly agree to strongly disagree.

\section{Reliability:}

Equation of Cronbach's Alpha is used by the researcher to measure the reliability. It is a measure for internal consistency. It was found that the reliability coefficient of the study is highly ranged between 0.79 and 0.81 . This indicates that the questionnaire has a high degree of reliability.

Validity: to measure the external validity, the questionnaire was presented to the arbitrators, assistant professors in King Saud University and Shaqra University, as well as English supervisors in Ministry of Education. Some changes were done in the statements. According to their views, the researcher prepared a tool which appears in its final format (see Appendix 3).

The internal validity of the questionnaire has been calculated using Pearson Correlation Coefficient. The values of Pearson correlation coefficient are statistically significant at level $(0.01)$ which shows the validity of their consistency with the themes.

\subsection{Procedure for Data Collection}

Before the data collection started, official permission to visit the schools selected was obtained from the Saudi Ministry of Education. From March 14, 2010 until April 7, 2010, the researcher distributed two tests to two control groups. Group one consists of 29 students who study English at Alajial Elementary School (level four); while group two consists of 24 students learning English at Alrwad Intermediate School (Grade-3). The administration of each test took 40-50 minutes, and subjects allowed revising their answers.

Because Saudi students have two monthly tests and a final test administered at the end of the term, the subjects were told that their answers would not affect their marks in English. They were also, except females, told that their answers would remain confidential and that no one in school would see or evaluate them. It was brought to the attention of the subjects that the English syllabus would be subject to possible amendment in response to the findings of the study. The subjects, therefore, were urged to exert sincere efforts so the researcher could obtain a true image of their competence in English.

\subsection{Data Analysis}

In order to test the research hypotheses, several analyses were required. These analyses required comparison of young students' performance (level-4 elementary school) with older students' performance (level-3 intermediate level).

Because it was desired to test hypotheses regarding the age of EFL instruction initiation, SPSS was used to analyze the data. There was a three-way analysis of variance. The independent variable was the starting age of learning EFL within two types of school programs, public intermediate school and private elementary school, because this variable separated those who have early EFL instructions (private elementary school) from those who have later EFL instructions (public intermediate school).

All comparisons and analyses were conducted using the conventional .05 Alpha level, which is to say that findings were not termed significant unless they could have been obtained on the basis of chance alone in only 5 out of 100 
times.

Means and standard deviations for each construct were calculated to determine the effects of age variable.

\subsection{Methods of Statistical Treatment}

To achieve the objectives of the study and analysis of data collected, several statistical methods have been used such as (SPSS). This happened after data was encoded and entered into the computer, and to determine the length Likert Scale (minimum and maximum) used in the statements of the study.

In this study, the following statistical analysis has been carried out:

1) Pearson correlation coefficient was used to verify the relationship between the independent and dependent variables of the study.

2) The weighted arithmetic mean "Weighted Mean" has been calculated so as to know how high or low responses of subjects on each of the statement in the basic variables of the study in the order of statements according to the highest weighted arithmetic average.

3) The arithmetic mean "Mean" has been calculated to see how high or low responses of samples of the study on the main axes (average of averages and statements).

4) The standard deviation is used to identify the deviation of responses of subjects of the study for each of the statements in the study variables. Each axis of the main hub is identified for the arithmetic average. It is noted that the standard deviation shows the distribution in the responses of study samples for each of the statements in the study variables as well as major hub.

5) T- test was used ( $t$ ) for independent samples (Independent Samples T-test) to identify whether there were statistically significant differences between the two independent groups in the study.

6) T-test was used ( $t$ ) for interrelated samples (Paired Samples T-test) to identify whether there were statistically significant differences between the two interrelated groups in the study.

\section{Findings of the Study}

\subsection{Findings of the Question of the Study}

Is there a significant difference between Saudi students who start learning English at age 5/6 as compared with those who do it at age $12 / 13$ ?

This Study found out that:

1. The performance of students who begin learning a foreign language at an earlier age (5/6) is better than those who start later (12/13).

2. The younger students they are, the better they will learn English.

3. Young learners speak English more fluently than adult learners.

The subjects agree on three statements from the effects of age on learning English as a foreign language in the Kingdom of Saudi Arabia, these are:

a- The young students are much better than the adult ones in acquiring vocabulary.

b- The suitable age to start learning EFL is the age of 5-6.

c- The performance of students who start learning EFL at the age of 12/13 and have studied the language for four years is weak.

The findings of this study tend to support the common belief that the earlier the better in language learning (Johnson 1990; Newport, 1990; Brown, 1994).

\subsection{Results of the Hypothesis of the Study}

Students who start learning English at an earlier age (5-6) attain higher level of proficiency than those who start at later stage (age 12/13).

The findings of the students' tests for English skills: conversation, vocabulary learning, reading, writing and grammar (see Table 2) show that the performance of students who started learning English at age 5-6 (in private schools) is significantly better than those who did it at the age of 12-13 (in public schools).

According to the findings of the study, there were statistical significant differences at level 0,01 or less between Saudi male students who started learning EFL at age 5-6 years and those who started learning EFL at age 12-13 years in grammar, vocabulary, conversation and writing skills in favour of the younger students (who started 
learning English at age 5-6 years).

There were statistical significant differences at level 0,01 or less between Saudi male students who started learning EFL at age 5-6 years and those who started learning EFL at age 12-13 years in reading skills in favour of the older students (who start learning English at age 12/13).

Thus, the summary of the tests' results according to the age groups clarifies the differences between the two groups. However, comparison can only be made across scores of each level because grade- 4 test is more complex. Therefore, the results of grade- 3 test versus that of grade- 4 cannot be meaningfully compared.

These findings support the statement that EFL learning is more rapid and complete when it started at earlier ages (Asher \& Garcia, 1999; Fathman 1995 ...etc).

Also support the findings of the Critical Period Hypothesis $(\mathrm{CPH})$ of Penfield \& Roberts who believed that: children acquire languages with ease before the age of 9 .

In addition, these findings strongly support those of Al Dali (1997) who concluded that "children who began learning EFL in private school around age 5/6 exhibited greater level of English achievement than did those who began learning English at ages 10/11 in public schools.

However, the current study differs from hers in that she did not consider motivation and she did not measure conversation or grammar. Her study runs in different community which has positive attitudes towards learning English.

\section{Summary}

In the light of the previous findings, one can assume that age affects EFL learning because early exposure to language instructions constantly resulted in better performance.

Throughout the review of literature, two studies were similar closely to the current study in that they were run in Arabic context, in which students learn English as a foreign language. The first study was of Abdan's (1988-1991) in Saudi Arabia. He examined two English skills: reading comprehension and writing comparing between public-school students (third level), who studied English for three years at that time, with private-school students (third level) who studied English for nine years. In fact, Abdan considered different starting age but as the same time he considered different time span ( 3 years for group-1 and 9 years for group -2). Abdan also examined these skills just for male without putting into account neither female students nor female teachers. Accordingly, this study differs greatly from Abdan's study, although it runs in Saudi context, in that it considers students' speaking skills and females took place in this study as students and as teachers. The time factors are four years for all students but the starting age is different (5/6 with 12/13 years of ages). The second study was of Al Dali (1998) who examined age, gender, and geographical districts in Kuwait. Although she emphasized on starting age, Al-Dali did not consider students' motivation and attitudes towards the target language. Her study runs in a community which has positive attitudes towards learning English. Also, the current study has the more time span for learning EFL (4 years) samples of her study had learning EFL for 3 years. From this review of the literature, there is no persuasive argument for starting at any particular age before puberty.

\section{Conclusion}

Essentially, the first question of the study asked whether the age had effect on learning English as a foreign language in Saudi Arabia.

In this field, established studies show that the earlier the first language learning, the better the second language general fluency (Snow, 1993; Taylor, 1990). Clearly, the findings of this study supported the established studies.

It concluded that the performance of foreign language was better in students who started learning English at an earlier age (5-6).

\section{Recommendation of the Study}

1. A primary recommendation is that a future research on EFL learning should attempt to replicate this study in other Arab countries to explore the effect of age on learning English as a foreign language.

2. Similar studies could be done at a higher level of education in Saudi Arabia, that of secondary school, in which the students of both types of schools would have started English at different ages but would have continued EFL exposure for a longer period of time.

3. It is recommended that experiment of learning English at age six should be begun in public schools in KSA. Then, similar studies can be conducted on these experimental schools and those results can be compared with students' achievements in private schools. 
4. Ministry of Education in KSA should make contribution to strengthen the capacity of learners to learn English as a foreign language in Saudi Arabia.

5. Ministry of Education in KSA should encourage the learning of English as a foreign language at early ages. The results showed that start learning English at an earlier age is an important factor in enhancing the skills of English language learners.

6. It is very important to develop appropriate ways to remove obstacles faced by learners in the field of learning English as a foreign language in Saudi communities.

7. English language teachers in different stages should motivate their students when learning English language.

8. There is a need for establishing language workshops and seminars looking at how to strengthen the students desire to learn English as a foreign language.

9. Hard work should be done to increase awareness of the importance of learning English among students at different academic levels.

10. It is very important to work on activating the role of parents in the follow-up and evaluate the levels of their children in English.

\section{Suggestions for Further Studies}

1. A future research should concentrate on female students because in Saudi Arabia the researcher faced some difficulties in dealing with Saudi female students and female supervisors of English.

2. It is very important to search the effects of time factor on learning EFL in any other research because sometimes the duration of the study plays a vital role in the process of learning.

3. A future research should consider foreign private schools for males and females (like Indian and Pakistani schools). These schools can be found in Riyadh.

\section{References}

Abdan, A. (1991). The Effect of Sentence, Syntactic Maturity, Overall Writing Quality and Reading Comprehension of EFL Saudi Students, PhD. University of Kansas, USA.

Al-Dali, A. (1997). The Age Variable, PhD. UMI, Bill \& Howell Information Company, USA.

Asher, J., \& Garcia, R. (1969). The Optimal Age to Learn a Foreign Language. Modern Language Journal, 53, 334341. http://dx.doi.org/102307/323026

Asher, J. (1972). Children's First Language as a Model for Second Language learning. Modern Language Journal, 56, 3, 133-139. http://dx.doi.org/10:1016/50388-0001(87)80019-0

Brown, H. (1994). Principles of Language Learning and Teaching. Englewood Cliffs NJ: Prentice Regents, San Francisco.

Cameron, L. (2001). Teaching Languages to Young Learners. Cambridge University Press. Cambridge, UK.

Cenoz, J. (2001). The Influence of Age in the Acquisition of English as a Third Language. Madrid.

Cenoz, J. (2007). Teaching English as a Third Language: The Effect of Attitudes and Motivation. In C. Hoffman, \& S. Ytsme (eds.), Trilingualism in Family, School and Community. Clevedon: Multilingual Matters. pp. 212-218. http://dx.doi.org/10:1080/09658419908667129

Conttia, L. (2007): The Influence of Learner Motivation on Developing Autonomous Learning in ESP Course. Master Degree, University of Hong Kong, China.

Fathman, A. (1975). The Relationship between Age and Second Language Productivity Ability. Language Learning, 25, 245-253. http://dx.doi.org/10:1111/j. 1467-1770

Johnson, J. S., \& Newport, E. L. (1990). Critical Period Effects in Second Language Learning. The Influence of Maturational State on the Acquisition of English as a Second Language. Cognitive psychology, 31(1), 60-99

Johnson, J. (1992). Critical Period Effect in Second Language Acquisition: The Effects of Written Versus Auditory Materials on the Assessment of Grammatical Competence. Language learning, 42, 217-248

Newport, E. L. (1990). Maturational Constraints on Language Learning. Cognitive Science, 14, 11-28. University of Rochester. http://dx.doi.org/10:106/03640213(90)90024-Q

Penfield, W., \& Roberts L. (1967). Speech and Brain Mechanism. Princeton, NJ: Princeton University Press.

Snow, C. E. (1993). Bilingualism \& Second Language Acquisition. Fort Worth, TX: Harcourt Brace Jovanovich. 
Taylor, I., \& Taylor, M. (1990). Psycholinguistic: Learning and Using Language. Englewood Cliffs, NJ: Preatice-Hall. MA: Newbury House.

Zhao, J. (2010). Language and Education: A Review of modern language in the primary school, http://dx.doi.org/10-1080/09500780903509910

Table 1. Pearson correlation coefficients of the statements for the first variable (age effects on learning EFL)

\begin{tabular}{|c|c|c|c|}
\hline Statement No. & $\begin{array}{c}\text { Correlation } \\
\text { Coefficients }\end{array}$ & Statement No. & Correlation Coefficients \\
\hline 1 & $* * 0.367$ & 7 & $* * 0.587$ \\
\hline 2 & $* * 0.379$ & 8 & 0.621 \\
\hline 3 & $* * 0.569$ & 9 & 0.539 \\
\hline 4 & $* * 0.353$ & 10 & 0.432 \\
\hline 5 & $* * 0.497$ & 11 & 0.450 \\
\hline 6 & $* * 0.522$ & - & - \\
\hline
\end{tabular}

** Correlation is significant at the 0.01 level (2-tailed).

Table 2. The results of "Independent Samples Test" for the differences between Saudi students who start learning English at ages 5/6, as compared with those who start learning English at the ages 12/13

\begin{tabular}{|c|c|c|c|c|c|c|}
\hline Skills & Age groups & $\mathrm{N}$ & Mean & Std. Deviation & T-test & Sig. \\
\hline \multirow[t]{2}{*}{ GRAMMAR } & $5-6$ years & 100 & 7.12 & 2.869 & \multirow{2}{*}{4.451} & \multirow{2}{*}{$* * 0.000$} \\
\hline & $12-13$ years & 30 & 5.22 & 3.280 & & \\
\hline \multirow[t]{2}{*}{ VOCABULARY } & $5-6$ years & 100 & 5.63 & 2.819 & \multirow{2}{*}{8.775} & \multirow{2}{*}{$* * 0.000$} \\
\hline & $12-13$ years & 30 & 3.58 & 1.612 & & \\
\hline \multirow[t]{2}{*}{ CONVERSATION } & $5-6$ years & 100 & 3.35 & 1.281 & \multirow{2}{*}{8.531} & \multirow{2}{*}{$* * 0.000$} \\
\hline & $12-13$ years & 30 & 2.15 & 1.250 & & \\
\hline \multirow[t]{2}{*}{ READING } & 5-6 years & 100 & 5.20 & 2.046 & \multirow{2}{*}{-4.664} & \multirow{2}{*}{$* * 0.000$} \\
\hline & $12-13$ years & 30 & 7.51 & 2.891 & & \\
\hline \multirow[t]{2}{*}{ WRITING } & $5-6$ years & 100 & 3.53 & 0.810 & \multirow{2}{*}{3.524} & \multirow{2}{*}{$* * 0.000$} \\
\hline & $12-13$ years & 30 & 2.47 & 1.106 & & \\
\hline \multirow{2}{*}{ TOTAL } & 5-6 years & 100 & 25.84 & 7.588 & \multirow{2}{*}{3.928} & \multirow{2}{*}{$* * 0.000$} \\
\hline & $12-13$ years & 30 & 21.92 & 6.185 & & \\
\hline
\end{tabular}

**significant differences at 0.01 level or less. 
Table 3. Responses of the subjects related to the effect of age on learning EFL in KSA in descending order according to the average approval

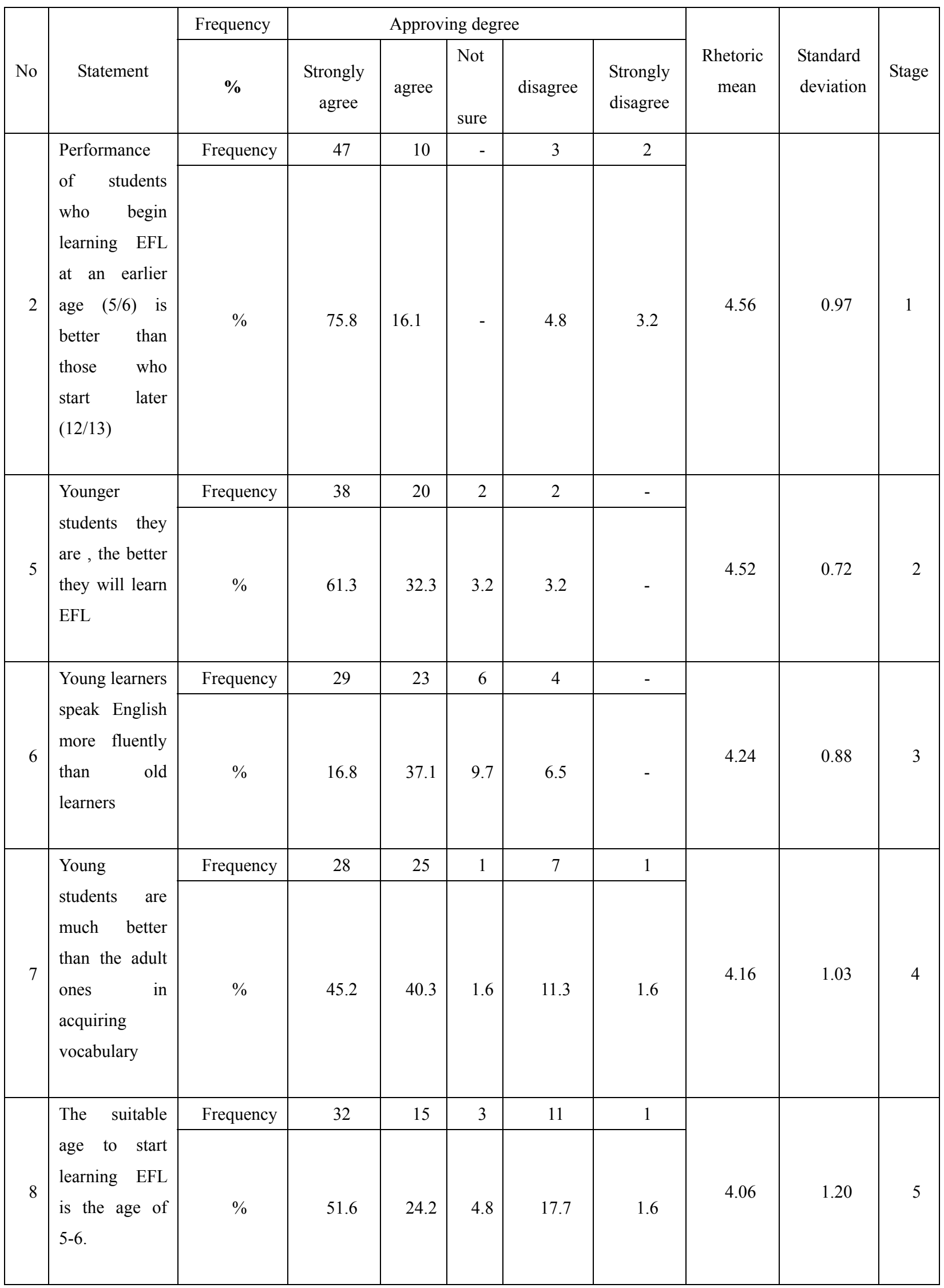


Table 4. Followed by Table 3

\begin{tabular}{|c|c|c|c|c|c|c|c|c|c|c|}
\hline \multirow[b]{2}{*}{ No } & \multirow[b]{2}{*}{ Statement } & Frequent & \multicolumn{5}{|c|}{ Approving degree } & \multirow{2}{*}{$\begin{array}{c}\text { Rhetoric } \\
\text { mean }\end{array}$} & \multirow{2}{*}{$\begin{array}{l}\text { Standard } \\
\text { deviation }\end{array}$} & \multirow[b]{2}{*}{ Stage } \\
\hline & & $\%$ & $\begin{array}{c}\text { Strongly } \\
\text { agree }\end{array}$ & agree & $\begin{array}{l}\text { Not } \\
\text { sure }\end{array}$ & Disagree & $\begin{array}{l}\text { Strongly } \\
\text { disagree }\end{array}$ & & & \\
\hline \multirow[b]{2}{*}{1} & \multirow[b]{2}{*}{$\begin{array}{l}\text { Performance of } \\
\text { students who start } \\
\text { learning EFL at the } \\
\text { age of } 12 / 13 \text { and } \\
\text { have studied the } \\
\text { language for four } \\
\text { years is weak }\end{array}$} & Frequency & 17 & 34 & 3 & 7 & 1 & & & \\
\hline & & $\%$ & 27.4 & 54.8 & 4.8 & 11.3 & 1.6 & 3.95 & 0.97 & 6 \\
\hline \multirow[b]{2}{*}{4} & \multirow{2}{*}{$\begin{array}{l}\text { Adult learners are } \\
\text { better than younger } \\
\text { ones in reading } \\
\text { skills }\end{array}$} & Frequency & 9 & 26 & 3 & 19 & 5 & \multirow[b]{2}{*}{3.24} & \multirow[b]{2}{*}{1.26} & \multirow[b]{2}{*}{7} \\
\hline & & $\%$ & 14.5 & 41.9 & 4.8 & 30.6 & 8.1 & & & \\
\hline \multirow[b]{2}{*}{11} & \multirow{2}{*}{$\begin{array}{l}\text { It is better for } \\
\text { students to start L2 } \\
\text { after mastering L1 }\end{array}$} & Frequency & 9 & 19 & 5 & 16 & 13 & \multirow[b]{2}{*}{2.92} & \multirow[b]{2}{*}{1.42} & \multirow[b]{2}{*}{8} \\
\hline & & $\%$ & 14.5 & 30.6 & 8.1 & 25.8 & 21.0 & & & \\
\hline \multirow[b]{2}{*}{3} & \multirow[b]{2}{*}{$\begin{array}{l}\text { Students who start } \\
\text { learning English at } \\
\text { the ages of (12-13) } \\
\text { are better in } \\
\text { grammar than } \\
\text { younger ones (5-6 } \\
\text { years). }\end{array}$} & Frequency & 8 & 17 & 5 & 25 & 7 & \multirow[b]{2}{*}{2.90} & \multirow[b]{2}{*}{1.29} & \multirow[b]{2}{*}{9} \\
\hline & & $\%$ & 12.9 & 27.4 & 8.1 & 40.3 & 11.3 & & & \\
\hline \multirow[b]{2}{*}{10} & \multirow{2}{*}{$\begin{array}{r}\text { Learning EFL in } \\
\text { Kindergarten may } \\
\text { confuse students } \\
\text { with L1 }\end{array}$} & Frequency & 5 & 11 & 11 & 221 & 14 & \multirow[b]{2}{*}{2.55} & \multirow[b]{2}{*}{1.25} & \multirow[b]{2}{*}{10} \\
\hline & & $\%$ & 8.1 & 17.7 & 17.1 & 33.9 & 22.6 & & & \\
\hline \multirow[b]{2}{*}{9} & The best age to & Frequency & 1 & 7 & 3 & 28 & 23 & \multirow[b]{2}{*}{1.95} & \multirow[b]{2}{*}{1.02} & \multirow[b]{2}{*}{11} \\
\hline & learn EFL is $12-13$. & $\%$ & 1.6 & 11.3 & 4.8 & 45.2 & 37.1 & & & \\
\hline
\end{tabular}

Source: The statistical analyses of the data collected from the subjects of the study samples. 
Appendix 1. Questionnaire

\begin{tabular}{|l|ll|}
\hline Gender : & (a) Male [ ] & (b) Female [ ] \\
\hline age : & (a) 20-30[ ] (b) 30-40 [ ] (c) More than 40 yrs [ ] \\
\hline Qualifications: (a) Bachelor [ ] Master [ ] PhD [ ] \\
\hline (b) Educational [ ] Non- educational [ ] \\
\hline Experience : (a) Less than 5 [ ] & (b) 5-10 (c) 1o-15 [ ] (d) More than 15 years [ ] \\
\hline
\end{tabular}

This questionnaire helps in the research to evaluate "Age, Gender, and Motivation Variables" in learning EFL at Dawadmi elementary schools (fourth level) and public intermediate schools (third level) for the completion of $\mathrm{PhD}$ degree. Can you, please, give your input by answering the following questions to contribute to this stud? Choose $A$, $\boldsymbol{B}, \boldsymbol{C}, \boldsymbol{D}$ or $\boldsymbol{E}$. Answer according to how far you agree with each of them and write it in the box.

\section{A: strongly agree B: agree C: not sure D: disagree E: strongly disagree}

1-The performance of students who start learning EFL at the age of 12/13 and have studied the language for four years is weak.

2-The performance of students who begin learning a foreign language at an earlier age (5/6) is better than those who start later (12/13).

3-Students who start learning English at the ages of (12-13) are better in grammatical rules than younger ones (5-6 years).

4-Adult learners are better than younger ones in reading skills

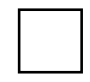

5-The younger students they are, the better they will learn English.

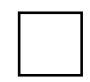

6-Young learners speak English more fluently than adult learners.
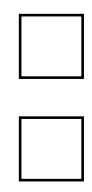

7-The young students are much better than the adult ones in acquiring vocabulary.

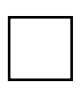

8-The suitable age to start learning EFL is the age of 5-6.

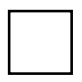

9-The best age to start learning EFL is 12-13.

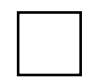

10-Learning a foreign language in Kindergarten may confuse students with L1

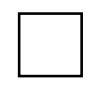

11- It is better for students to start L2 after mastering L1.

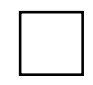

\section{Appendix 2. Intermediate Schools' English Test Grade Three}

Student name:...............Age [ ] Male/Female ............

\section{[1] Grammar [10 marks]:}

\section{Choose the correct answer:}

1 - I can stop the blender by . (press - presses - pressing) the button off.

2-While she was (cooking - cook - cooks), he watched TV.

3-Ramadan is the month (where - when - who) all Muslims fast. 
4-It ....... (is - was - were) so busy in the school library yesterday.

5- As I was buying a book, I (met - meet - meeting) a friend.

6-They told me that they .... (write - wrote - written) the correct answer.

7- Ahmed is (tall - tallest - taller) than Ali.

8- You should (sleep - sleeps - sleeping) early.

9- She reads (slow - slowly - slower).

10- I think he will (be - is - was) very successful.

[2] Vocabulary [10 marks]:

A. Complete each sentence with a suitable word from the box:

\begin{tabular}{|c|}
\hline Friends - fancy - Venice - ourselves - February - view \\
1-Last ............., we went to .............. A city in Italy.
\end{tabular}

2-We lived in a hotel which had a garden.

3-The rooftop restaurant had a beautiful of the city.

4-The weather was nice and warm and we enjoyed

B. Choose the correct answer:

1 - If someone is on the phone, their line is (busy - full).

2- An (environment - invention) is a thing that someone has created.

3-Start the (car - computer) and play in the flash disc.

4-How does a (water - camera) work?

5 -You call your friends by using your (mobile - remote).

[3]Conversation [5 marks]:

\section{Complete the following dialogue:}

Ali: Good morning Ahmed

Ahmed: , Ali.

Ali: Could you have dinner with me tonight?

Ahmed: Yes,

Ali: Is it good to come at 9.00 o'clock?

Ahmed: Yes,

Ali: Do you like Kabsa?

Ahmed: No,

Ali: Good bye Ahmed.

Ahmed:

\section{[4] Reading [10 marks]:}

\section{Read the following passage, then answer the questions below:}

Each society has its own customs, beliefs and behaviours. Communicating in a foreign language is not just a matter of using correct grammar and vocabulary. It is also a matter of understanding other cultures and traditions. We need to understand and respect other customs. Differences are seen in many aspects of daily life such as: greetings, dining, clothing, and ceremonies. Here are some customs from different parts of the world:

In the Middle East, you must take off your shoes before entering someone house. In addition, in the USA, it is usual for men to shake hands when they meet, but it is unusual for them to kiss each other.

\section{Questions:}

\section{A. Answer by true or false:}

1- People all over the world have the same customs. 
2- Speaking a foreign language means just using correct grammar and vocabulary. ( )

3-We should accept other people and their customs.

4- American men kiss while greeting.

5- In the Middle East people take off their shoes before entering a house. ( )

\section{B. Choose the correct answer:}

1-The best title for this passage is

a- Different Customs b-Communication c. Greetings in USA

2-It line-3 refers to
a. behaviours
b. Societies
c. Communicating in a FL

3-customs means (greeting - traditions - communication)

4-usual (L.9) is (noun - adj. - adv.)

5-There are (one - two - three) paragraphs in the passage.

\section{[5] Writing:}

Using the words in the box, write a paragraph about "An Invention"

$$
\text { First - second -finally - on - off - invent - shape - press - connect - start }
$$

\section{Appendix 3. Foreign and Private Schools Education English Test For Elementary Schools-Grade Four}

\section{[1] Grammar:}

Student name:............... Age [ ] Male/Female ............

\section{A. Choose the correct answer [5 marks]:}

1- (Which/ What/ When) did Jessica do?

2-(When/ Whose/ Who) ball is that?

3- I cannot (play/ played/ playing) base ball.

4- (He/ It/ They) A cheap car.

5- The kids (have/ has) seen the giraffes.

\section{B. Do as shown [5 marks]:}

1-Change the verbs in to past simple:
a. come
b. do
c. send

2-Add the correct 'present simple' form of the verb in brackets:

- In our house, Sally and I (live) on the first floor.

3- Change the verb in brackets in present perfect:

- Oh yes, Stella's using her new camera. She has (take) lots of photos.

\section{[2]Conversation [5 marks]:}

\section{Complete the following dialogue:}

Ali: What's your name?

Hind: My

Ali: Where are you from?

Hind: I

Ali: How old are you?

Hind: I'm

Ali: How are you? 
Hind:

Ali: What's your favourite subject?

Hind:

[3] Vocabulary[10 marks]:

Match the words in ' $B$ ' with their meanings in ' $A$ ':

\begin{tabular}{|c|c|}
\hline (A) & (B) \\
\hline 1-Things that can fly in space & a. list \\
\hline 2. A person who lives nearby & b. blink \\
\hline 3. Heavy rain and thunder & c. competition \\
\hline 4. A sheet of paper on which you can write ( ) & d. space ship \\
\hline 5. Cry out loudly & e. neighbour \\
\hline 6. To shut and open the eyes quickly & f. storm \\
\hline 7. To speak with pauses and repeated sound ( ) & g. scream \\
\hline 8. A person solving a crime & h. stammering \\
\hline 9. A loud cry of pain & i. waiting \\
\hline 10. Contest & j. detective \\
\hline
\end{tabular}

[4] Reading [10 marks]:

Read the paragraph carefully. If you think the answer is correct, put ' $A$ ' and if you think it is incorrect put ' $B$ ' with the statements given below:

\section{$\underline{\text { Don't accept bad service }}$}

\section{Be polite:}

Don't shoot! Becoming angry or emotional won't help you. keep calm, speak slowly but firmly and make it clear that you won't go away until someone listens to you.

\section{Go to the top:}

Shouting at the shop assistant is not a good idea. Go straight to the top and ask to speak to the manager.

\section{Know what you want:}

The law says that if the goods are not working properly or are broken, you should get your money back.

\section{Collect information:}

take photo of damaged goods keep all receipt and guarantees, and make copies of any letters you have sent or received.

\section{Set time limits:}

Seven days is long enough for the shop to reply to letter of complaint, so don't wait too long before you make further complaint.

\section{Be reasonable:}

If you ask for a fair amount of money, you are more likely to get it than if you ask for too much.

\section{Questions:}

1- If you speak loudly, your complaint will be heard clearly

2. It is better to complain to the manager than to the shop assistant

( )

3. You never get the money back for broken goods

4. Keep copies of all the letters you have sent to the shop

5. If the shop doesn't reply to your letter in 7 days, you should complain again ( )

6. Don't ask for too much money back

7. The opposite of calm (L2) is noisy

( )

8. damaged (L8) means unbroken

9. slowly is adjective
( )

( ) 
10. manager means director

\section{( )}

\section{[5] Writing [5 marks]:}

Write a 'friendly letter' inviting your friend to come and stay in your house in the weekend. Use the words in the box:

The weekend - stay - my house - on Thursday - go - Dammam - beaches - swimming - collect shells - eat - fish - enjoy ...etc. 